\title{
An Empirical Analysis on Legitimacy of Sukuk: An Insight of Malaysian Sukuk
}

\author{
Essia Ries Ahmed ${ }^{1}$, Md. Aminul Islam ${ }^{1} \&$ Ku Halim Ku Ariffin ${ }^{1}$ \\ ${ }^{1}$ School of Business Innovation \& Technopreneurship, Universiti Malaysia Perlis, Malaysia \\ Correspondence: Essia Ries Ahmed, School of Business Innovation \& Technopreneurship, Universiti Malaysia \\ Perlis, Penang, Malaysia. Tel: 60-17-381-9769. E-mail: essa_ahmed15@yahoo.com
}

Received: October 4, 2014 Accepted: March 20, 2015 Online Published: May 16, 2015

doi:10.5539/ass.v11n13p84 URL: http://dx.doi.org/10.5539/ass.v11n13p84

\begin{abstract}
Islamic Sukuk have a key impact and high influence in different economic and banking transactions where they have got an estimable position in financial markets and international money. Recently, sukuk have been considered as one of the fastest industries in its growth in international financial landscape and also considered as the most successful financial products among the Islamic financial institutions. Institutions should be giving more attention to sukuk development and to ensuring that these sukuk are compliant with Sharia requirements. The main objective of this paper is to determine the factors which influencing on sukuk legitimacy. A total of 54 Islamic sukuk Islamic financial institutions in Malaysia representing the whole population were selected. Secondary data was used and sourced from the sukuk shariah report. Using descriptive statistics, the existence and the extent of existence of legitimacy in Islamic sukuk in Islamic financial institutions in Malaysia was ascertained. The research found that the selected factors influence on sukuk legitimacy are could be used as subjects of references in determining the existence of legitimacy in shariah pronouncements.
\end{abstract}

Keywords: Sukuk legitimacy, pricing, rating, Shariah, risks and documentation

\section{Introduction}

One of the main challenges of sukuk that its return relies on usually benchmarked to the LIBOR on \$US dollar funds (Kantakji, 2012). This therefore leads to an interest rate which is used only for pricing. However, such a case is dealing with riba, which is a controversial issue among shariah scholars (Usmani, 2002).

The problem for the financial institutions is that they pursue to convey the belief of the investors to regard the sukuk as similar to conventional asset rather than being distinctive from a financial viewpoint, as this simply risk valuation. Investors are more comfortable than if a security has a common structure better than being unknown. Thus, the innovation with sukuk is uniquely legal; their unique characteristic being shariah compliance, but there has been no financial innovation (Wilson, 2008). Because sukuk have familiar structures, agencies of risk rating are ready to rate sukuk in such a way there will be assurance for the investors by the global leader, Standard and Poor's, or the agency that is specializing in Middle Eastern banks' rating. Specialist rating agency in Islamic sukuk has been established through the Islamic development Bank (IDB), and in Malaysia the rating agency has got wide experience of sukuk evaluation, yet the criteria that have been used are similar to other rating institutions. Thus, the main objective of this paper is to focus on factors (pricing, rating, shariah auditing, shariah compliance risk and shariah documentation) which are essential elements that have important impact on sukuk Legitimacy.

\section{Concept of Sukuk Securities}

Sukuk is the standard Arabic term for Securities or Bonds structured according to the principles of Shariah and referred to as Sukuk, Islamic bonds, Islamic trust certificates or Islamic debt security (AL-Bashir, 2008).

In addition, Sukuk are securities that comply with the Islamic shariah Law and its investment principles, which prohibits the paying, charging of interest (LMC, 2008). Sukuk are certificates of equal values representing undivided shares in ownership of tangible assets, usufruct and services or in the ownership of the assets of particular projects or investment activity (AAOIFI, 2007; LMC, 2008). Moreover, Sukuk is an asset-backed, tradable, stable income and Shariah compatible trust certificates. The primary conditions of issuance of Sukuk are the existence of assets on the balance sheet of the government, the corporate body, the monetary authority, 
the financial institution or any entity which wants to mobilize the financial resources. The determination of suitable assets is the first and arguably most integral step in the process of issuing certificates of Sukuk. Shariah considerations state that the group of assets should not only be comprised of debts from Islamic financial contracts such as Istisna or Murabahah (Al-Buolayan, 2006; LMC, 2008).

Furthermore, the Accounting and Auditing Organization of Islamic financial Institutions (AAOFI) defines the Investment Sukuk on the Shariah Standard No.17 as "certificates of equal value representing undivided shares in ownership of tangible assets, usufruct and services or in ownership of the asset of a particular project or special investment activity, however, this is true after receipt of the value of the Sukuk, the closing of subscription and the employment funds received for the purpose for which the Sukuk are issued " (AAOIFI, 2008). Also, the AAOFI listed the Sukuk types that are mostly used as the Musharakah Sukuk,Ijarah Sukuk, Murabahah Sukuk, Istisna Sukuk, Mudarabah Sukuk, and combination of some of these types if feasible (AL-Bashir, 2008).

In accordance with the Islamic Financial Services Board (IFSB) "Sukuk (plural of sakk), frequently referred to as 'Islamic bonds', are certificates with each sakk representing a proportional undivided ownership right in tangible assets, or a pool of predominantly tangible assets, or a business venture. These assets may be in a specific project or investment activity in accordance with Shariah rules and principles" (IFSB, 2009).

The Malaysia Securities Commission defines the Islamic securities (Sukuk) as "any securities issued pursuant to any Shariah principles and concepts approved by the Shariah Advisory Council ("SAC") of the SC as set out in Appendix 1 (and subsequently) Appendix 1 (B): A document or certificate which represents the value of an asset" (SC Malaysia, 2004 Para 1.05 a \& SC Malaysia, Lexis Mexis, 2009). However, first the steps involving in the issuance of Sukuk prepare a detailed feasibility study. Second, they set up a general framework and an organizational structure. Third, they work out an appropriate Shariah structure. Fourth, they arrange lead manager. Fifth, they arrange agreed Shariah legal documentation. Sixth, they set up the special purpose vehicle (SPV) to represent the investors. Finally, they put Sukuk into circulation (LMC, 2008). The model of Sukuk security is derived from the conventional securitization process in which a special purpose vehicle (SPV) is setup to acquire assets and to issue financial claims on the assets. These financial assets claims represent a proportionate beneficial ownership to Sukuk holders (Al-Buolayan, 2006).

\section{Factors Influencing on Sukuk}

In spite of the development of the Islamic finance industry in many respects and the growing demand both domestically and internationally on trading of Sukuk, there are a number of factors which are influencing on Sukuk legitimacy (Al-Suwailem, 2007; Taqi Usmani, 2009; Naoual 2011; Kamal, 2009).

Some researchers and scholars have pointed out the need to reconsider the method of structure and marketing of Islamic Sukuk that are impeded by current model to achieve the desired goals. The target audience from Sukuk is mostly conventional bonds audience in addition to the return of Sukuk, which is more like a return of conventional bonds in terms of relates to (LIBOR), or in terms of risks, or in terms of subscriptions and marketing through brokers. This led to become limited liquidity of Sukuk due to the limited size of Sukuk that offered for traded in the secondary market.

Therefore, the target audience must be the audience shares not the audience bonds, which would reduce risks as well as costs of issuance and marketing. Thus, investors will be able to take advantage of the high-return from these Sukuk (Al-Suwailem, 2007). Investment Sukuk are the ideal investment for investors requiring a fixed investment return with low risk and the Shariah Compliant (Khalil, 2011).

Admittedly, there are a host of factors influencing the sukuk legitimacy, but as an exploratory study, this research will only investigate characteristics of the Islamic sukuk, such as pricing, rating, shariah auditing, shariah compliant risks, shariah documentation and shariah supervisory board. The reasons being, arguably, they are the significant characteristics with which investors, Islamic financial institutions and regulators will look at in determining the Islamic sukuk legitimacy to Shariah. Furthermore, the selected characteristics are very general in nature and readily available in the sukuk's shariah reports.

As this research, to the author's knowledge, is of the pioneer in studying sukuk legitimacy, there is a dire need to specify the relationship between sukuk legitimacy and above-mentioned factors.

The pricing benchmark has a significant role of legitimacy in influencing the sukuk in general. It is influential factor that has impact on the sukuk legitimacy as confirmed by several previous studies in the literature (See Kantakji, 2012; Usmani, 2011; Omar, Azmi, Noor, \& Meera, 2010; Al-Bashir, 2008).

Rating agencies is classified rating of sukuk into two categories; asset-based and asset-backed sukuk. Such classification effects on the compliance and legitimacy of sukuk as mentioned by (Yean \& Wan, 2009). 
Asset-based sukuk, as showed by Mohammed Khnifer (2010), is riskier than asset-backed sukuk and might lead to default of sukuk. Furthermore, according to Hidayat (2013), the compliance asset backed sukuk structure with the rule of shariah is much more than asset based structure.

Islamic Sukuk need to have their own Shariah borads to ensure its compliance and legitimacy with the Shariah principles, and such boards should be composed of Shariah experts. To safeguard that Islamic financial institutions perform their transactions according to the shariah requirements, there should be a preciece control in the financial institution which represented by shariah supervisory board (SSB) (Lahsana, 2010). A Shariah Supervisory Board (SSB) normally consists of fiqh muamalat experts to guide their operations and transactions in accordance with the rules of Shariah. Therefore, Shariah Supervisory Board undoubtedly forms the most important and influential entity in any Islamic financial institution (Mass, 2010) to be shariah-compliant and better containing legitimacy. therefore, Shariah operation documents need to be reviewed and oversee by the Shariah supervisory board to provide the fatwa that lies in approving sukuk that give expression for the legitimacy of mechanisms and structure of sukuk. This is due to those documents are core matter to make sukuk compliant to Shariah (Rahail, 2011). Thus, any negligence or even mistake might lead to difficulties in issuing the sukuk as well as the probability to increase the shariah compliance risks. The study therefore hypothesizes that:

H1: There is positive relationship between pricing and sukuk legitimacy.

H2: There is position relationship between ratings and sukuk legitimacy.

H3: There is negative relationship between Shariah Compliance Risks and sukuk legitimacy.

H4: There is position relationship between Shariah Auditing and sukuk legitimacy.

H5: There is position relationship between Shariah Documentation and sukuk legitimacy.

\begin{tabular}{|l|}
\hline Pricing \\
\hline Rating \\
\hline Shariah Auditing \\
\hline Shariah Compliance Risks \\
\hline Shariah Documentation \\
\hline
\end{tabular}

Figure 1. Theoretical framework

\section{Methodology}

This paper aims to investigate and detect legitimacy of sukuk in shariah reports (pronouncement). The study was conducted on population of the Islamic financial institutions in Malaysia. The quantitative data were collected from the shariah reports of the identified Islamic sukuk. The population of this study is the sukuk issuance by Islamic Financial Institutions in Malaysia. The population size in this study consists of 54 sukuks in Islamic Financial Institutions in Malaysia will be selected, which represents a full sample for seven consecutive years' period from 2005 to 2013. Therefore, the entire population was studied without taking smaller samples for the analysis. SPSS (Statistical Package of Social Science) version 19.0 will be used in the analysis of the data. The data collection processed through different statistical techniques such as (Descriptive Statistics, Correlations Analysis and Multiple Regressions).

\subsection{Variables Measurement}

Dependent Variable: To measure sukuk legitimacy disclosure, the current study used content analysis as a way for measuring sukuk legitimacy, where the literature review shows that this way is employed in social disclosure (Rahman et al., 2010; Maali et al., 2006; Gray et al., 1995; Zeghal \& Ahmed, 1990).

Several previous studies were done to develop a relevant list of social information that must be disclosed by Islamic financial institutions. Yet, a few empirical studies have developed disclosure index with Shariah compliant information, particularly for Islamic financial institutions (Haniffa \& Hudaib, 2007; Maali et al., 2006; Muwazir et al., 2006). Therefore, the present paper is the first to take in its account the using of three new parts as new structures that compose the Shariah committee report: structure and mechanisms of sukuk legitimacy; sukuk documentation and the last lies in Shariah compliance. 
The previous studies in the literature review dealing with content analysis of the social disclosure studies have adopted the number of words, sentences and sometimes pages as the preferred units of analysis as a method to determine the disclosure degree (Gray, Kouhy, \& Lavers, 1995). According to (Williams, 1999), these previous studies theoretically did not give any detailed illustration for preferring/choosing any of them and neglecting the others. The researchers in the current paper suggest using the number of sentences method to measure sukuk legitimacy disclosure for four reasons: Firstly, to ensure increasing the validity of content analysis (Milne \& Adler, 1999); secondly, as used by Ingram, \& Frazier (1980), they selected sentences as the unit of analysis, reporting that "a sentence is easily identified, is less subject to inter judge variations than phrases, classes and themes, and has been evaluated as an appropriate unit in previous research"; and thirdly, as shown by (Hughes \& Anderson, 1995), sentences are more accepted than individual words. Nonetheless, as argued by Milne and Adler (1999), the single word itself is neglected to be as "words" because it doesn't express a certain meaning, without being completed with other words; fourthly, comparing a sentence to words and pages, a sentence could be as a very applicable unit of writing and speech (Walden \& Schwartz, 1997; Hackston \& Milne, 1996). Finally, as Oxibar and Déjean (2003) believe, among all these methods, a sentence is considered better than other methods in terms of reliable data for analysis.

Milne and Alder (1999) show that the main concern of content analysis is to focus on the reliability and moreover on the instruments used for data collected. They argue that the reliability could be achieved by using two ways. These two ways are employing multiple and single coders who must be given enough time to reach reasonable and acceptable level of skills. While (Krippendorff, 2004) in his study focuses on the types of reliability, he mentions that there are two types of reliability: the first one is stability, which shows the ability of a coder to code data in the same way over time and consequently it can decrease the dire need for multiple coders. The second lies in the accuracy used in measuring a review coding performance with a pre-established standard.

Pricing: Islamic pricing benchmark model to estimate the rate of return of any sukuk considering expected future cash flows, which is relative to the capital invested. The future cash flows are supposed to take into account the economic conditions prevailing (i.e. growing or recession), and other prevailing factors (Kantakji, 2012). Islamic pricing benchmark model allows access to the rate of return through cash flow assumptions that resemble the internal rate of return (IRR) mechanics, or aim to the determination of net cash flows to be achieved when the return reaches the target simulating the approach of the Net Present Value (NPV) without the need to base on the interest rate; such as in LIBOR or SIBOR, ... etc. Thus, pricing sukuk will be measured based on using Islamic benchmark or conventional benchmark.

Rating: Rating sukuk will be measured on the basis of asset-backed or asset-based sukuk, depending on ratings of the Malaysian Rating Corporate MARC's and the Rating Agency Malaysia Bhd (RAM).

Shariah compliance risk: Shariah compliance risk will be measured (Content Analysis) based on the Shariah report of SSB and documentation of sukuk contracts.

Shariah Auditing: Shariah auditing will be measured (Content Analysis) based on Opinion and Recommendations of Shariah Report.

Shariah documentation: documentation will be measured by number of disclosure of shariah documentation that raising at shariah pronouncement.

\section{Result}

\subsection{Descriptive Analyses of Pricing}

The Table 1 shows that out of the 54 selected sukuk, 41 sukuk (i.e. 75.9 percent) have Shariah Pricing compared to 13 sukuk (24.1percent) with Non-Shariah Pricing. The descriptive statistic showed that most of the Islamic Sukuk in Malaysia has a Shariah majority of pricing.

Table 1. Pricing of Sukuk

\begin{tabular}{llll}
\hline & Frequency & Percent & Valid Percent \\
\hline SH-PRICING & 41 & 75.9 & 75.9 \\
Non-SH PRICING & 13 & 24.1 & 24.1 \\
Total & 54 & 100.0 & 100.0 \\
\hline
\end{tabular}




\subsection{Rating of Sukuk}

Table 2 shows that the Rating of Sukuk in the Islamic Financial Institutions were 42.6 percent for the Sukuk-based (i.e. 23 Sukuk), and 57.4 for the Sukuk-backed (31 sukuk), respectively. The descriptive statistic showed that most of the Islamic Financial Institutions in Malaysia have a majority of Sukuk-backed.

Table 2. Rating of Sukuk

\begin{tabular}{llll}
\hline & Frequency & Percent & Valid Percent \\
\hline Based & 23 & 42.6 & 42.6 \\
Backed & 31 & 57.4 & 57.4 \\
Total & 54 & 100.0 & 100.0 \\
\hline
\end{tabular}

\subsection{Shariah Auditing}

Table 3 describes the percentage of Shariah Auditing on the Islamic sukuk. The descriptive statistic showed that only one sukuk has the shariah auditing of sukuk 1.9 percent and 17 sukuk the shariah auditing of sukuk 31.5 percent. And 7 sukuk have the shariah auditing of sukuk 13.0 percent. And 23 sukuk have the shariah auditing of sukuk 42.6 percent. And 6 sukuk have the shariah auditing of sukuk 11.1 percent.

Table 3. Statistics of Shariah auditing

\begin{tabular}{llll}
\hline & Frequency & Percent & Valid Percent \\
\hline Valid & 1 & 1.9 & 1.9 \\
1 & 17 & 31.5 & 31.5 \\
2 & 7 & 13.0 & 13.0 \\
3 & 23 & 42.6 & 42.6 \\
4 & 6 & 11.1 & 11.1 \\
Total & 54 & 100.0 & 100.0 \\
\hline
\end{tabular}

Table 4 describes the Percentage of Shariah auditing report on the selected Islamic sukuk. Results showed that only 18 sukuk has the report of shariah auditing less than 2 report with 33.3 percent and 36 sukuk have the report of shariah auditing above 2 report with 66.7 percent. The descriptive statistic showed that most of the Islamic sukuk in Malaysia have a majority of report of shariah auditing above 2 reports.

Table 4. Shariah auditing reports

\begin{tabular}{llll}
\hline & Frequency & Percent & Valid Percent \\
\hline Less than 2 & 18 & 33.3 & 33.3 \\
Above 2 & 36 & 66.7 & 66.7 \\
Total & 54 & 100.0 & 100.0 \\
\hline
\end{tabular}

\subsection{Shariah Complaint Risk}

Table 5. Statistics of Shariah complaint risk

\begin{tabular}{llll}
\hline & Frequency & Percent & Valid Percent \\
\hline Valid & 2 & 3.7 & 3.7 \\
1 & 38 & 70.4 & 70.4 \\
2 & 5 & 9.3 & 9.3 \\
3 & 4 & 7.4 & 7.4 \\
4 & 5 & 9.3 & 9.3 \\
Total & 54 & 100.0 & 100.0 \\
\hline
\end{tabular}


Table 5 describes the percentage of Shariah Risks on the Islamic sukuk. The descriptive statistic showed that only two sukuk has the shariah risk of sukuk 3.7 percent and 38 sukuk the shariah risks of sukuk 70.4 percent. And 5 sukuk have the shariah risks of sukuk 9.3 percent. And 4 sukuk have the shariah risks of sukuk 7.4 percent. And 5 sukuk have the shariah auditing of sukuk 9.3 percent.

Table 6 describes the Percentage of shariah complaint risk on the selected Islamic sukuk. Results showed that only two sukuk has the risk of shariah complaint less than one risk with 5.6 percent and 52 sukuk have the risk of shariah complaint above one risk with 96.2 percent. The descriptive statistic showed there are three sukuk did not have risks based on shariah complaint, (3.8 percent).

Table 6. Shariah complaint risk

\begin{tabular}{llll}
\hline & Frequency & Percent & Valid Percent \\
\hline Less than 1 & 2 & 3.8 & 3.8 \\
Above 1 & 52 & 96.2 & 96.2 \\
Total & 54 & 100.0 & 100.0 \\
\hline
\end{tabular}

\subsection{Shariah Documentation}

Table 7 illustrates the percentage of shariah documentation on the Islamic sukuk. The descriptive analysis revealed that 16 sukuk have 12 shariah documentation that represented 29.6 percent. Moreover, there are 12 sukuk have 8 shariah documentation with percent of 22.2. In addition, there are 6 sukuk have one shariah documentation with 11.1 percent. Furthermore, the table showed that 5 sukuk have 13 shariah documentations with percent 9.3. The result of this table also showed that 4 sukuk have 9 shariah documentations with percent 7.4. The results also explained that 4 sukuk have 10 shariah documentations 7.4 percent. Further, there are 4 sukuk have 11 shariah documentations 7.4 percent. Finally, there are 3 sukuk have 7 shariah documentations 5.6 percent.

Table 7. Statistics of Shariah documentation

\begin{tabular}{llll}
\hline & Frequency & Percent & Valid Percent \\
\hline Valid & 6 & 11.1 & 11.1 \\
7 & 3 & 5.6 & 5.6 \\
8 & 12 & 22.2 & 22.2 \\
9 & 4 & 7.4 & 7.4 \\
10 & 4 & 7.4 & 7.4 \\
11 & 4 & 7.4 & 7.4 \\
12 & 16 & 29.6 & 29.6 \\
13 & 5 & 9.3 & 9.3 \\
Total & 54 & 100.0 & 100.0 \\
\hline
\end{tabular}

An explanation is shown in Table 8 that describes the percentage of shariah documentation on the Islamic sukuk. The results revealed that only 9 sukuk has the shariah documentation are less than 3 documentations with 16.7 percent. Moreover, there are 45 sukuk have the shariah documentation that above 3 documentations with 83.3 percent. The descriptive statistic showed that most of the Islamic sukuk in Malaysia have a majority of shariah documentation that have more than 3 documentations.

Table 8. Shariah documentation

\begin{tabular}{llll}
\hline & Frequency & Percent & Valid Percent \\
\hline Less than 3 & 9 & 16.7 & 16.7 \\
Above 3 & 45 & 83.3 & 83.3 \\
Total & 54 & 100.0 & 100.0 \\
\hline
\end{tabular}




\subsection{Descriptive Statistics on Sukuk Legitimacy}

The cross tabulation analysis has been used to analyse the sukuk legitimacy in the Islamic financial institutions. Table 9 reports on legitimacy of sukuk in Islamic institutions. The percentage of sukuk legitimacy was between 0.16-0.92 percent. There are 15 sukuk have legitimacy between 0.16-0.38 percent. And 13 sukuk have legitimacy between 0.39-0.63 percent. And 14 sukuk have legitimacy between 0.64-0.73percent. And only 2 sukuk have legitimacy $0.74-0.90$ percent. The descriptive statistic showed that most of the Islamic sukuk in Malaysia have a majority of legitimacy.

Table 9. Statistics of sukuk legitimacy

\begin{tabular}{llll}
\hline & Frequency & Percent & Valid Percent \\
\hline Valid .16 to .38 & 15 & 28.1 & 28.1 \\
.39 to .63 & 13 & 24.4 & 24.4 \\
.64 to .73 & 14 & 26.2 & 26.2 \\
.74 to .92 & 2 & 21.3 & 21.3 \\
Total & 54 & 100.0 & 100.0 \\
\hline
\end{tabular}

\section{Correlation Analysis}

The last part of preliminary analysis considered was the bivariate correlations between the constructs incorporated in both the measurement and theoretical framework. Correlation analyses were applied to determine the degree to which the variables are related. It determines how well the estimated equation actually describes the relationship (Levin \& Rubin, 2007).

The values of correlation coefficients reflect the degree of association between each of these variables. The Pearson's range between -1.00 and +1.00 in size where 0 represents no relationship between variables, and a value of -1.00 or +1.00 indicates perfect correlation (Tabachnick \& Fidell, 2007). In interpreting the correlation coefficients for this study, the correlation values of \pm 0.5 and above reflect strong correlations between tow variables. However, the correlation values with more than 0.8 should be interpreted with cautions as thy may indicate the presence of multicollinearity that may result in the bias finding (Gujarati, 2003).

The correlation between the dependent and independent variables is shown in Table 10.The report showed that 4 independent variables have positive relationship with sukuk legitimacy and only one independent variable (shariah-risk) have a negative relationship with sukuk legitimacy, with values (pricing .745), (rating .812), (sh-audting .664), (shariah-risk -.472) and (shariah-documentation .408). The report showed that rating has highly positive relationship with sukuk legitimacy with value .812 .

Table 10. Correlations between variables

\begin{tabular}{lllllll}
\hline & Pricing & Rating & Sh-Audit & Sh-risk & Sh-doc & Sukuk-leg \\
\hline Pricing & 1 & & & & & \\
Rating & $.654^{* *}$ & 1 & & & & \\
Sh-Audit & $.634^{* *}$ & $.547^{* *}$ & 1 & & & \\
Sh-risk & -.416 & $-.478^{* *}$ & $.333^{*}$ & 1 & & \\
Sh-doc & .230 & .270 & $.291^{*}$ & .249 & 1 & \\
Sukuk-leg & $.745^{* *}$ & $.812^{* *}$ & $.664^{* *}$ & $-.472^{* *}$ & $.408^{* *}$ & 1 \\
\hline
\end{tabular}

**. Correlation is significant at the 0.01 level (2-tailed).

*. Correlation is significant at the 0.05 level (2-tailed).

\section{Regression Analysis}

In order to test hypotheses $(\mathrm{H} 1, \mathrm{H} 2, \mathrm{H} 3, \mathrm{H} 4, \mathrm{H} 5)$ that postulated positive and negative relationship between independent variables (Pricing, rating, shariah auditing, shariah complaint risk and shariah documentation) and dependent variable (sukuk legitimacy), there was one step of hierarchical regression equation that carried out. In step one; the independent (predictor) variables were introduced to test their marginal effect on the dependent variable. 
A report on Table 11 with R square value of .805 for sukuk legitimacy, the R square value is explaining $80.5 \%$ from independent variables (pricing, rating, shariah auditing, shariah risk and shariah documentation) on dependent variable (sukuk legitimacy).

Table 11. R Square of sukuk legitimacy

\begin{tabular}{ll}
\hline Model & Sukuk Legitimacy \\
\hline R Square & .805 \\
Sig F Change & .000 \\
\hline
\end{tabular}

Table 12 was found that all independent variables have positive relationship with the sukuk legitimacy, (pricing .246, rating .419, sh-aud .149 and sh-doc .240) except shariah complaint risk was negative relationship with sukuk legitimacy where it was -.180 . The result showed that the pricing has a significant impact on sukuk legitimacy where it was at $\mathrm{P}<0.01, \beta=0.246$. It shows that the larger Shariah pricing the higher legitimacy of sukuk. Therefore, $\mathrm{H} 1$ has been supported. Moreover, as regards of rating, the results show that it has been a positive relationship with sukuk legitimacy $\mathrm{P}<0.05, \beta=0.419$. This result indicates that the higher rating the higher legitimacy of sukuk. Then H2 is supported. Furthermore, the result show that shariah auditing has a significant effect on the legitimacy of sukuk where it was $\mathrm{P}<0.01, \beta=0.149$. It show that the sukuk have shariah auditing the higher legitimacy. Therefore, $\mathrm{H} 3$ is supported. In addition, the results show that shariah complaint risk has been a negative relationship with the sukuk legitimacy where it was $\mathrm{P}<0.01, \beta=-.240$. It shows that the sukuk haven't shariah complaint risks the higher legitimacy. Therefore, H4 is supported. It is worth mentioning that the results also show that the shariah documentation has been a positive relationship with sukuk legitimacy where it was $\mathrm{P}<0.01, \beta=0.240$. This result indicates that the higher shariah documentation the higher legitimacy of sukuk. Therefore, H5 is supported as well. In general, these results give support for the assertion that the sukuk characteristics leads to the creation of legitimacy of sukuk.

Table 12. Regression result: Relationship between independent variables and Sukuk legitimacy

\begin{tabular}{ll}
\hline & Sukuk Legitimacy \\
& Standardized Coefficients \\
\hline Independent Variables & Beta \\
Pricing & .246 \\
Rating & .419 \\
Sh-Aud & .149 \\
Sh-risk & -.180 \\
Sh-Doc & .240 \\
\hline
\end{tabular}

In this study the hypotheses that were set before the analysis shown acceptance for the variables proposed in this study, all hypotheses were supported.

\section{Discussion}

\subsection{Evaluation of the Legitimacy of Sukuk}

For the legitimacy of sukuk, the findings showed R square value of $80.5 \%$, this indicates that the independent variables interpreted $80.5 \%$ of the legitimacy of sukuk, and the remaining $19.5 \%$ represented other factors related to legitimacy of sukuk which are not included in the scope of this study. Furthermore, the results showed that the average value of sukuk legitimacy by all sukuk selected is .570 percent and the number ranges .76 percent. As for the level of legitimacy, the minimum level of legitimacy for sukuk is.16 percent and the maximum level of legitimacy for sukuk is .92 percent. In addition, the results showed that the impacts of independent variables on legitimacy of sukuk were small relationship for pricing; medium relationship for rating; small relationship for shariah auditing; small relationship for shariah risks and small relationship for bank shariah documentation. It can be noticed that the rating had the highest influence (Medium) on legitimacy with a value of .419 percent followed by the pricing which supports all the hypotheses (i.e. H1, H2, H3, H4, and H5) illustrated earlier in the previous section. 


\subsection{The Impact of Pricing on Sukuk Legitimacy}

Pricing is one of the most important factors that impacts on the legitimacy of the sukuk. The pricing is another point of criticism against Islamic sukuk (Usmani, 2002). Shariah scholars and Muslim economists have not come up with an alternative to the interest rate as a readily available indicator of profitability (Al-Bashir, 2008). Hence the use of LIBOR as a benchmark has become part of the practice in Islamic financial institutions. The factors for computing pricing benchmark should be free from interest rates, non-real economic activities, and non-halal activities such as indices of financial derivatives instruments (Omar, Azmi, Noor, \& Meera, 2010). However, what shall be noted is that while it is permissible to use LIBOR as a pricing benchmark it is not correct to rely on it for determination of returns (Kantakji, 2012). Therefore, pricing of sukuk will be an effect to structure of the sukuk to comply more with rules of shariah and Increase the legitimacy. Thus, the influence of the pricing on legitimacy of sukuk was studied. The findings of the study have supported this hypothesis with a relation between pricing and sukuk legitimacy indicated by the positive value in the results.

The results showed that 75.9 percent of sukuk legitimacy based on Islamic pricing benchmark, while 24.1 percent based on non- Islamic pricing benchmark. This highlights that majority of the sukuk pricing in Islamic financial institutions in Malaysia follow Islamic pricing benchmark. We can be considered a positive relationship between pricing and sukuk legitimacy because there is influence from pricing on structure and legitimacy applied by the Islamic financial institutions. The more compliant with the shariah principles whenever the pricing increase the legitimacy on Islamic sukuk through the induction of audit sukuk characteristics to ensure that sukuk compliant with the shariah principles.

\subsection{The Impact of Rating on Sukuk Legitimacy}

Sukuk can be classified (Rating) usually into two different categories: asset-backed and asset based instruments (IFSB guidelines No. 2, 2005). Rating is one of the factors that affect the legitimacy of sukuk. A declaration was made in late 2007 by the Chairman of the AAOIFI board of scholars, Sheikh Usami, that some 85\% of outstanding Sukuk had failed the Shariah-compliance test. They failed because they were asset-based and not asset-backed with the guaranteed return of the face value of the Sukuk on maturity without transfer in asset ownership to Sukuk holders (MARC, 2008).

The difference between asset-based and asset-backed Sukuk have since been made known by the rating agencies as shown by some chosen application of asset-backed securities rating methodology to Sukuk transactions. Sukuk like the conventional market benchmark - bonds - are exposed to credit risk. Credit risk refers to the risks that occurs due to the failure of a business partner to timely and fully meet its obligations in accordance with the agreed terms (Khan \& Ahmed, 2001). It also refers to the likelihood of an asset or loan becoming impossible to get back because of default or delay in settlements (Tariq \& Dar, 2007).

Therefore, the rating of sukuk based on (asset-based and asset-backed) has been influencing on the legitimacy of sukuk. When the Islamic sukuk is asset-backed will be more complied with rules of shariah and increasing the legitimacy.

Two ratings were investigated: asset-based and asset-backed sukuk. The aim is to determine which sukuk rating effect more on legitimacy of sukuk. The results showed that asset-backed sukuk have differed from asset-based sukuk in issues to shariah compliance, where the asset-backed sukuk have an impact of more asset-based sukuk to increase the legitimacy. This means that the asset-backed sukuk have more compliance to the rules of shariah more than asset-based sukuk to increase sukuk legitimacy. On the other hand the results show relationship that the rating has on sukuk legitimacy. The rating has positive relationship toward the sukuk legitimacy.

The results have shown a noticeable difference between asset-based and asset-backed sukuk in terms of increase legitimacy. Asset-backed sukuk have more impact on sukuk legitimacy enhancement and have shown more comply with the rules of shariah to increase the legitimacy of sukuk compared to asset-based sukuk. Results have shown a positive relationship between rating and sukuk legitimacy indicating the significant effect of rating on legitimacy enhancement.

\subsection{The Impact of Shariah Auditing on Sukuk Legitimacy}

Shariah Auditing is the single most important element that distinguishes between conventional and Islamic bonds. It is the only way of certifying that its operations and procedures are actually Shariah-compliant. In the emerging Islamic financial industry, therefore, Shariah auditing has to be considered as a significant factor (Lahsana, 2010).

Sukuk has a feature as a financial instrument that should be undertaken in accordance with Shariah rules. Therefore, as Hamid et al. (1993) argue, it is important that sukuk implementation has to be compliant with 
Shariah principles in order to be as a vital and preferred alternative choice in the current business environment. The role of Shariah is so important in the business world because of its concern for justice, honesty and goodwill, preventing on the other hand any prohibitions on uncertainties and fraud. The recommendations by Shariah to Muslims for conducting their business transactions are based on ethical behaviour side by side in giving attention to social responsibility (Kasim, 2012).

This is very important in this study, since all Islamic sukuk under this study have shariah auditing in their organizations, the study emphasize the importance of this shariah auditing, and their usefulness to the Islamic financial institutions. Apart from shariah auditing ensures the Islamic sukuk under right direction and also complies with rules of shariah to increase the legitimacy. The results of the study were supported this relation, and the results showed that most of the Islamic sukuk in financial institutions have a majority of report of shariah auditing had done their duty and work accurately and legitimacy and least of report of shariah auditing did not perform their duty and work accurately and legitimacy. When sukuk reached to two shariah auditing report or above is considered high had done their duty and work accurately and legitimacy, and shows that effective role by shariah auditing in performed.

The more compliance with the rules of shariah whenever the shariah auditing increases the legitimacy on Islamic sukuk through the induction of shariah auditing to ensure that sukuk have more legitimacy. The findings show that a shariah auditing has relationship with sukuk legitimacy. There exists a positive association between shariah auditing and sukuk legitimacy. Therefore, the shariah auditing and sukuk legitimacy are found to be positively related since shariah auditing obligated to shariah provisions practices.

\subsection{The Impact of Shariah Compliance Risk on Sukuk Legitimacy}

The Shariah compliance risk is one of important elements that have impact on the sukuk legitimacy (Ali Tariq, 2004). If scholars opine differently, it might endanger the market view of the Shariah- compliance of a sukuk which may influence the audacious of investors to support the instrument and hitting prices (Jadwa, 2009).

The risk has shown up significantly in the late 2007. For instance one of the key members and chairman of the Accounting and auditing organizations of Islamic Financial Institutions (AAOIFI), Taqi Usmani made a public pronouncement to the surprise of the sukuk market. He indicated that there is no much difference between sukuk and interest based securities like bond since the later do not follow the Shariah strictly (Kokab, 2010). Therefore, the association of Shariah supervisors with Sukuk issues will ensure investor confidence (Ali Tariq, 2004; AL-Maghlouth, 2009). All operations and structure of sukuk should be free from shariah risk and compatible with legitimacy of Islamic law.

Results showed that 3.8 percent of sukuk do not have shariah complaint risks. In addition, the results show that shariah complaint risk has been a negative relationship with the sukuk legitimacy where it was negative value. In that, when less shariah complaint risks this leads to increasing and enhancing legitimacy. It shows that the sukuk haven't shariah complaint risks the higher legitimacy. Results have shown a negative relationship between shariah complaint risks and sukuk legitimacy indicating the significant effect of shariah complaint risks on increasing of legitimacy. Thus, sukuk with a low of shariah complaint risks have higher legitimacy.

\subsection{The Impact of Shariah Documentation on Sukuk Legitimacy}

Shariah documentation for Islamic Sukuk is often split into what are colloquially called "capital markets documents' and "Shariah transaction documents" (Rahail, 2011). The designation is, of course, imprecise because all sukuk documents must be comply with Shariah required and they can also all be said to be capital markets documents, given the nature of the tool being issued. However, the terminology does serve to split sukuk documentation understanding into documents which should follow capital market norms relating to custody, documents, payment and administration generally, which form the core of Shariah compliant transaction. In addition, previous studies such as Haniffa and Hudaib (2007) and Maali et al. (2006), admit that Islamic financial institutions and their insights are very useful to improve disclosure in the Shariah Committee report of the Islamic financial instruments.

Sukuk require the audit the legal documents to guarantee that all conditions and terms in such documents do not conflict with the Shariah. Different legal documentations in sukuk issuance have to be arranged. This actually needs accurate examination and auditing through Shariah supervisory board to give guarantee that there are no items incompatible with the Shariah principles. A set of responsibilities should be carried out by Shariah supervisory board; in that, advising on documentation, structuring, and all aspects of the sukuk such as a matter dealing with shariah pronouncement that should be based on the rationality of the pronouncement in addition to the structure and mechanisms of the sukuk issue. Moreover, Shariah principles and its concepts used in the sukuk 
issue should be compliant as recommended by Shariah Advisory Council (SAC). In addition, Shariah matters should be compatible with the documentation of the sukuk issue (Kasim, 2012). Whatever structure is used, the Shariah transaction documents will need to be reviewed by the Shariah scholars providing the fatwa for the sukuk because those documents form the essence of the sukuk for Sharia compliance. Thus, the influence of the Shariah documentation on sukuk legitimacy was studied. The findings of the study have supported this hypothesis with a relation between Shariah documentation and sukuk legitimacy indicated by the positive value in the results. The results highlights that most of the Islamic sukuk have a majority of shariah documentation above three documentations. It is worth mentioning that the results also show that the shariah documentation has been a positive relationship with sukuk legitimacy where it was positive value. Thus, the higher the number of shariah documentation the higher the legitimacy. Therefore, Islamic financial institutions and their insights are very useful to improve disclosure of shariah documentation in the Shariah Committee report of the Islamic sukuk, since that improving disclosure on Shariah documentation is inevitable not only to distinguish amongst the Islamic financial products themselves but also with that of the counterparts. The results showed that shariah documentation have a significant impact to increase of legitimacy. In that, there is a good relation between the shariah documentation and sukuk legitimacy indicated by the positive value in the results.

\section{Implications}

The findings highlight earlier leads to several implications. The discussion on these implications will be divided into two perspectives namely, theoretical and practical.

\subsection{Theoretical Perspective}

First and foremost, the findings enrich the sukuk legitimacy literature. Furthermore, this study added a new discussion, i.e. legitimacy on the Islamic sukuk with its relationship with some selected characteristics of Islamic sukuk. Furthermore, it is a novel study since there are no previous studies, as to the author's knowledge that has covered this area from the Islamic finance perspectives.

This study would enlighten the Islamic Ummah and contribute to knowledge to provide clarification on the Islamic pricing benchmark fundamentals for further investigations and with more detailed description of the sukuk legitimacy. Furthermore, this study contributes to both academic and practitioner individuals. The findings may have some policy implications whereby the policy is made (shariah advisory council, Islamic financial institutions management).

The study is intended to increase public awareness for sukuk legitimacy in the importance of shariah compliancy not only in the form but also in substance. In addition, this study will be give more benefits for Islamic financial institutions in the sense that they should amend some of their regulatory frameworks to push the sukuk market investors to move towards asset backed structure.

This study also identified the relationship between sukuk and sukuk legitimacy which is a novel finding in the legitimacy research. This study should help to fill a gap exists in the literature of sukuk characteristics and sukuk legitimacy.

\subsection{Practical Perspective}

This study will be useful to the financial institutions, and to take into consideration identifying the sukuk characteristics that will enhance the legitimacy of sukuk, which has been shown through the previous study that the sukuk legitimacy in Islamic financial institutions in Malaysia is high. This study adds to sukuk characteristics and sukuk legitimacy studies in number of ways. Comprehensive analysis demonstrates how different sukuk characteristics interact in analyzing the legitimacy in Malaysian context.

Shariah Supervisory Board (SSB) should promote the importance of and attention, and have increasing the legitimacy to Islamic sukuk. The committees of SSB in bank centrals must also look into the importance of increasing the legitimacy of sukuk and apply it to the Islamic financial institutions. The importance of increase and subsequently attention of legitimacy will also act as guideline for the financial institutions in their sukuk transactions. The Islamic financial institutions that increase will know their sukuk structure in conducting their sukuk operations that should not conflict with the shariah and affect the sukuk holders.

\section{Conclusion}

This study has made a unique contribution to the body of literature concerning the influence of sukuk characteristics (pricing, rating shariah auditing, shariah compliant risks and shariah documentation) on the sukuk legitimacy in population of Islamic financial institutions in Malaysia for period 2005-2013. The results of this study have revealed that the level of legitimacy of sukuk in Islamic financial institutions in Malaysia is high in 
general.

Surprisingly, the present study revealed that there is a positive relationship between sukuk characteristics (pricing, rating, shariah auditing and shariah documentation) and sukuk legitimacy. While shariah compliant risks as the fifth variable of sukuk characteristics has a negative relationship with sukuk legitimacy.

This study tested a research model that conceptualized the influence of sukuk characteristics on sukuk legitimacy. The research model was found to be sound and able to explain the variation in sukuk legitimacy indicators under study. The research found that the selected sukuk characteristics influence legitimacy could be used as subjects of references in determining the existence of legitimacy in Islamic sukuk. This is significant for at least three parties, i.e. investors, Islamic financial institutions and the relevant authorities' bodies, to strategize on containing the existence of the legitimacy in Islamic sukuk by accordingly controlling the selected characteristics, hence producing Islamic financial institutions that are more compliant to the shariah. The focus of the sukuk market and be acceptable to international financial institutions, although these are valid and well needed objectives, but to be Shariah compliant first and foremost. This will also help in the growth of real economy.

\section{References}

Accounting and Auditing Organization for Islamic Financial Institutions Accounting, Auditing \& Governance Standards (for Islamic Financial Institutions). (2008). Shariah Standards. Manamah.

AL-Bashir, M. (2008). Structuring Sukuk, a lecture wrote for MBA students. Retrieved from http://www. asiancampus.net

AL-Bashir, M. (2008). Sukuk Market: Innovations and Challenges. Islamic Economic Studies, 15(2).

AlBuolayan. (2006, July 17). Rapid Surge in Sukuk market. Retrieved from http://www.arabnews.com

AL-Maghlouth, A. K. (2009). Sukuk; an inside study of its background, structures, challenges \& Cases.

Al-suwailem. (2007). Role of sukuk in activating the function of financial markets, economic journal. Retrieved from http://www.kantakji.com/fiqh/Sukuk.htm

Déjean, F., \& Oxibar, B. (2003). An Alternative Approach to Evaluate Corporate Social Performance. In Trabajo presentado en el Congreso de la European Accounting Associa tion.

Gray, R., Kouhy, R., \& Lavers, S. (1995a). Corporate social and environmental reporting: A review of the literature and a longitudinal study of UK disclosure. Accounting, Auditing and Accountability Journal, 8(2), 47-77. http://dx.doi.org/10.1108/09513579510146996

Gray, R., Kouhy, R., \& Lavers, S. (1995b). Methodology themes construction research database of social and environmental reporting by UK companies. Accounting, Auditing and Accountability Journal, 8(2), 78-101. http://dx.doi.org/10.1108/09513579510086812

Gujarati, D., \& Porter, D. (2003). Multicollinearity: What happens if the repressors are correlated. Basic Econometrics, 363.

Hackston, D., \& Milne, M. J. (1996). Some determinants of social and environmental disclosures in New Zealand companies. Accounting, Auditing \& Accountability Journal, 9(1), 77-108. http://dx.doi.org/10. 1108/09513579610109987

Hamid, S., Craig, R., \& Clarke, F. (1993), Religion: A confounding cultural element in the international harmonization of accounting? Abacus, 29(2), 131-148. http://dx.doi.org/10.1111/j.1467-6281.1993.tb 00427.x

Haniffa, R., \& Hudaib, M. (2007). Exploring the ethical identity of Islamic banks via communication in annual reports. Journal of Business Ethics, 76, 97-116. http://dx.doi.org/10.1007/s10551-006-9272-5

Hidayat, S. E. (2013). A Comparative Analysis between Asset Based and Asset Backed Sukuk: Which One is More Shariah Compliant. International SAMANM Journal of Finance and Accounting, 1(2).

Hughes, S. B., \& Anderson, A. (1995). Corporate Environmental Performance and Environmental Disclosure: Are They Related? Paper presented at the American Accounting Association Annual Conference, Orlando, Florida, United States.

IFSB Islamic Financial Services Board (Malaysia) - IFSB Standard 7 - Capital Adequacy requirements for Sukuk, securitizations and real estate investment, para 1.1. (2009, January).

Ingram, R. W., \& Frazier, K. B. (1980). Environmental performance and corporate disclosure. Journal of accounting research, 614-622. http://dx.doi.org/10.2307/2490597 
Jadwa Investment. (2009). The Saudi Sukuk Market KFH, 2012. Islamic financial research. Retrieved from http://kfhresearch.com/uploads/reports/samples/a83549cedbdffaf7868eb8a90c0f03e60934cabd.pdf

Kamal. (2009a). Islamic investment sukuk and contemporary challenges. Islamic banks conference, dubai.

Kamal. (2009b). Maqasid al Shariah made simple. The International Institute of Islamic Thought IIIT.

Kasim, N. A. A. (2012). Disclosure of Shariah compliance by Malaysian takaful companies. Journal of Islamic Accounting and Business Research, 3(1), 20-38. http://dx.doi.org/10.1108/17590811211216041

Khalil. (2011). Sukuk: Definition, Structure and Accounting Issues, Islamic Science University of Malaysia (USIM). Retrieved from http://mpra.ub.uni-muenchen.de/33675/

Khnifer, M. (2010). Constructing Sukuk. Islamic Banking \& Finance, 8(1), 27.

Kokab, F. U. (2010). Chief Financial Officer. Lynchpin Financial Centre, Dubai.

Krippendorff, K. (2004). Reliability in content analysis. Human Communication Research, 30(3), 411-433. http://dx.doi.org/10.1111/j.1468-2958.2004.tb00738.x

Lahsasna. (2010). Shariah aspects in business and finance. INCEIF: Kuala Lumpur.

Levin, R. I., \& Rubin, D. S. (2007). Statistics for management (7th ed.). New Delhi: Prentice Hall Of India Private Limited.

LMC. (2008). The guide to Sukuk market. Liquidity Management Centre, Bahrain. Retrieved from http://www. Imcbahrain.com

Maali, B., Casson, P., \& Napier, C. (2006). Social reporting by Islamic banks. Abacus, 42(2), 266-289. http://dx.doi.org/10.1111/j.1467-6281.2006.00200.x

Malaysian Accounting Standards Board Discussion Paper i-2 Sukuk Comments to be received by 16 March 2012.

Malaysian Debt Securities and Sukuk Market. (2009). A Guide for Issuer and Investor. A joint Publication by Central Bank of Malaysia and Securities Commission Malaysia (pp. 29-34).

Malik, M. R. (2010). Shariah Supervisory Board in Islamic Finance. International Center for Education in Islamic Finance, INCEIF.

MARC. (2010). RATING APPROACH TO SUKUK: A MARC PERSPECTIVE. Malaysian Rating Corporation Berhad. Retrieved from http://www.marc.com.my/home/userfiles/file/Methodologies/Rating\%20 Approach\%20to\%20Sukuk\%20-\%20A\%20MARC\%20Perspective.pdf

MARC. (2010). Rating Symbols and Definitions. Kuala Lumpur. Malaysian Rating Corporation Berhad. Retrieved 10 September 2010. Retrieved from http://www.marc.com.my/.../Rating\%20Symbols\%20 $\& \% 20$ Definitions.pdf

Milne, M. J., \& Adler, R. W. (1999). Exploring the reliability of social and environmental disclosures content analysis. Accounting, Auditing \& Accountability Journal, 12(2), 237-256. http://dx.doi.org/10.1108/095 13579910270138

Mohammad, K. (2010). Stand and Default. Islamic Business \& Finance (Oct. ed.)

Muwazir, M. R., Muhamad, R., \& Noordin, K. (2006). Corporate Social Responsibility Disclosure: A Tawhidic Approach. Journal of Syariah, 14(1), 125-142.

Nauoal. (2011). Role of Islamic sukuk to development of Islamic financial Market. Journal of researcher, 9.

Nexis, L. (2009). AAOIFI Accounting and Auditing Organization for Islamic Financial Institutions (Bahrain) AAOIFI Standard 17 (20 - as quoted Securities Commission Malaysia, Islamic Capital Market) (Vol. 5, p. 9). The Islamic Securities (Sukuk) Market.

Nexis, L. (2009). Malaysia Securities Commission - Guidelines on the Offering of Islamic Securities 2004 - Para 1.05(a) - as quoted Securities Commission Malaysia, Islamic Capital Market (Vol. 5, p. 9). The Islamic Securities (Sukuk) Market.

Omar, Azmi, M., Noor, A. M., \& Meera, A. K. M. (2010). An Islamic Pricing Benchmark. ISRA Research Paper No. $17 / 2010$.

Rahail. (2011). Sukuk and Islamic Capital Markets. London: Globe Law and Business.

Rahman, A. A., Hashim, M. F. A. M., \& Bakar, F. A. (2010). Corporate Social Reporting: A Preliminary Study of 
Bank Islam Malaysia Berhad (BIMB). Issues in Social and Environmental Accounting, 4(1), 18-39.

Tabachnick, B. G., \& Fidell, L. S. (2007). Using multivariate statistics (5th ed.). Boston: Allyn and Bacon.

Tariq, A. (2004). Managing financial risks of Sukuk structures. Lough borough University, UK.

Tariq, A. (2007). Risks of Sukuk Structures: Implications for Resource Mobilization Thunderbird International Business Review.

Tariq, A. A., \& Dar, H. (2007). Risks of Sukuk Structures: Implications for Resource Mobilization. Thunderbird International Business Review, 49(2), 203-223. http://dx.doi.org/10.1002/tie.20140

Usmani, M. T. (2002). An Introduction to Islamic Finance (pp. 75-76). Kluwer Law International, The Hague.

Usmani, M. T. (2009). President of the AAOIFI Shariah Council, Sukuk and Their Contemporary Applications. Retrieved from February 6, 2011, from http://www.failaka.com/downloads/Usmani_SukukApplications.pdf

Usmani, M. T. (2011). President of the AAOIFI Shariah Council, Sukuk and Their Contemporary Applications. Retrieved February 6, 2011, from http://www.failaka.com/downloads/Usmani_SukukApplications.pdf

Walden, W. D., \& Schwartz, B. N. (1997). Environmental disclosures and public policy pressure. Journal of Accounting and Public Policy, 125-154.

Williams, S. M. (1999). Voluntary Environmental and Social Accounting Disclosure Practices in the Asia Pacific Region: An International Empirical Test of Political Economy Theory. The International Journal of Accounting, 34(2). http://dx.doi.org/10.1016/S0020-7063(99)00006-0

Wilson, R. (2008). Innovation in the structuring of Islamic $<$ IT $>$ sukuk $</$ IT $>$ securities. Humanomics, 24(3), 170-181. http://dx.doi.org/10.1108/08288660810899340

Yean, T. W. (2009). Sukuk: Issues and the way forward. International Legal News, 6(2).

Zeghal, D., \& Ahmed, S. A. (1990). Comparison of social responsibility information disclosure media used by Canadian firms. Accounting, Auditing and Accountability Journal, 3(1), 38-53. http://dx.doi.org/10.1108/ 09513579010136343

\section{Copyrights}

Copyright for this article is retained by the author(s), with first publication rights granted to the journal.

This is an open-access article distributed under the terms and conditions of the Creative Commons Attribution license (http://creativecommons.org/licenses/by/3.0/). 